\title{
The Neuroinflammatory Role of Pericytes in Epilepsy
}

\author{
Gaku Yamanaka 1,*(1), Fuyuko Takata ${ }^{2}$, Yasufumi Kataoka ${ }^{2}$, Kanako Kanou ${ }^{1}$, Shinichiro Morichi ${ }^{1}{ }^{(1)}$, \\ Shinya Dohgu ${ }^{2}$ and Hisashi Kawashima ${ }^{1}$
}

1 Department of Pediatrics and Adolescent Medicine, Tokyo Medical University, Tokyo 160-8402, Japan; kanako.hayashi.0110@gmail.com (K.K.); s.morichi@gmail.com (S.M.); hisashi@tokyo-med.ac.jp (H.K.)

2 Department of Pharmaceutical Care and Health Sciences, Faculty of Pharmaceutical Sciences, Fukuoka University, Fukuoka 814-0180, Japan; ftakata@fukuoka-u.ac.jp (F.T.); ykataoka@fukuoka-u.ac.jp (Y.K.); dohgu@fukuoka-u.ac.jp (S.D.)

* Correspondence: gaku@tokyo-med.ac.jp; Tel.: +81-3-3342-6111; Fax: +81-3-3344-0643

Citation: Yamanaka, G.; Takata, F.; Kataoka, Y.; Kanou, K.; Morichi, S.; Dohgu, S.; Kawashima, H. The Neuroinflammatory Role of Pericytes in Epilepsy. Biomedicines 2021, 9, 759. https://doi.org/10.3390/

biomedicines 9070759

Academic Editor: Prosper N'Gouemo

Received: 31 May 2021

Accepted: 26 June 2021

Published: 30 June 2021

Publisher's Note: MDPI stays neutral with regard to jurisdictional claims in published maps and institutional affiliations.

Copyright: (c) 2021 by the authors. Licensee MDPI, Basel, Switzerland. This article is an open access article distributed under the terms and conditions of the Creative Commons Attribution (CC BY) license (https:// creativecommons.org/licenses/by/ $4.0 /)$.

\begin{abstract}
Pericytes are a component of the blood-brain barrier (BBB) neurovascular unit, in which they play a crucial role in BBB integrity and are also implicated in neuroinflammation. The association between pericytes, BBB dysfunction, and the pathophysiology of epilepsy has been investigated, and links between epilepsy and pericytes have been identified. Here, we review current knowledge about the role of pericytes in epilepsy. Clinical evidence has shown an accumulation of pericytes with altered morphology in the cerebral vascular territories of patients with intractable epilepsy. In vitro, proinflammatory cytokines, including IL-1 $\beta, \mathrm{TNF} \alpha$, and IL-6, cause morphological changes in human-derived pericytes, where IL-6 leads to cell damage. Experimental studies using epileptic animal models have shown that cerebrovascular pericytes undergo redistribution and remodeling, potentially contributing to BBB permeability. These series of pericyte-related modifications are promoted by proinflammatory cytokines, of which the most pronounced alterations are caused by IL-1 $\beta$, a cytokine involved in the pathogenesis of epilepsy. Furthermore, the pericyte-glial scarring process in leaky capillaries was detected in the hippocampus during seizure progression. In addition, pericytes respond more sensitively to proinflammatory cytokines than microglia and can also activate microglia. Thus, pericytes may function as sensors of the inflammatory response. Finally, both in vitro and in vivo studies have highlighted the potential of pericytes as a therapeutic target for seizure disorders.
\end{abstract}

Keywords: pericytes; mural cells; cytokine; blood-brain barrier; neuroinflammation

\section{Introduction}

Accumulating evidence has demonstrated that the pathogenesis of epilepsy is linked to neuroinflammation and cerebrovascular dysfunction [1-6]. Traditionally, microglia had been considered to be responsible for the cytokine-centered immune response in the central nervous system (CNS); however, brain pericytes can respond to inflammatory signals, such as circulating cytokines, and convey this information to surrounding cells through chemokine and cytokine secretions [7-10]. Recent studies have demonstrated that pericytes may act as sensors for the inflammatory response in the CNS, as pericytes react intensely to proinflammatory cytokines when compared to other cell types (e.g., microglia) that constitute the CNS and factor-induced reactive pericytes can also activate microglia in vitro $[9,11-13]$.

Pericytes provide physical support to the blood-brain barrier (BBB) and play an integral role in CNS homeostasis and BBB function [14]. Pericyte degeneration and/or dysfunction contribute to the loss of BBB integrity, which is an early hallmark of several neurodegenerative and inflammatory conditions $[8,15,16]$. Another notable feature of pericytes is their ability to regulate the migration of leukocytes across the brain microvascular endothelial cell (BMVEC) barrier, which secretes key molecules that support the 
BBB barrier [17,18]. Recent research on the pathogenesis of epilepsy has begun to elucidate the mechanisms mediating peripheral-to-CNS cell infiltration in human and mouse models $[19,20]$. Pericytes may contribute to the mechanisms, while emerging research is investigating the extent of peripheral immune cell involvement in the inflammatory pathology of epilepsy.

The various functions of pericytes and their involvement in CNS diseases, including ischemic stroke [21], spinal cord injury [22], brain injury [23], and multiple sclerosis [24], has been reported.

The association between pericytes and epilepsy has attracted attention, while several recent studies have illustrated the contributions of pericytes to the pathogenesis of epilepsy [2,25-32]. These studies suggested that pericytes might participate in the pathogenesis of epilepsy, consisting of neuroinflammation and BBB damage and the interaction between peripheral and central immunity. Thus, evidence on the relationship between pericytes and the pathogenesis of epilepsy is gradually accumulating. Therefore, this study aimed to investigate the pathogenesis of epilepsy and pericytes because none of the review articles focused on this, even though therapeutic targets for pericytes in neurological disorders were investigated $[17,33,34]$.

This review (1) explores the current literature regarding the role of pericytes in the pathogenesis of epilepsy and (2) highlights novel directions for research on therapeutic interventions for epilepsy that target pericytes. Given the paucity of knowledge on pericyte function in seizures and epilepsy-related pathologies, further studies are warranted to investigate pericytes as a potential therapeutic target for epilepsy treatment.

\section{What Are Pericytes?}

Pericytes were first described by the French scientist Charles-Marie Benjamin Rouget and were originally called Rouget cells in 1873 [35]. Later, this population was rediscovered by Zimmermann as a cell that shows a specific morphology around microvessels, and became widely known as a "pericyte" [36]. Pericytes are mural cells that are implanted in the basal membrane surrounding endothelial cells in capillaries and small vessels, including precapillary arterioles and postcapillary venules. Although the origin of all pericytes has not been clarified, blood vessels in the CNS are predominantly covered by neural crest cell-derived pericytes, while mesoderm-derived pericytes mainly contribute to blood vessel coverage in the trunk [37]. In the brain, pericytes constitute a vital component of the BBB/neurovascular unit (NVU) and cover the BMVECs lining the capillaries on the parenchymal side, where there are astrocytic end feet that enclose cerebral vessels, perivascular microglia/macrophages, and neurons $[17,38,39]$. Pericytes form a crucial component of the brain microvasculature and play an integral role in CNS homeostasis and BBB function [14] in normal physiological (Figure 1) and pathological conditions (Figure 2). A potential mechanism of pericyte action is the regulation of signaling through plateletderived growth factor receptor beta (PDGFR $\beta$ ), which is commonly used as a marker of pericytes and regulates pericyte survival, proliferation, and migration signals [40]. In the CNS, platelet-derived growth factor-beta subunit (PDGF-BB) is released by endothelial cells and binds to PDGFR $\beta$ at the cell surface of pericytes to promote pericyte vascularization within the BBB [41]. The PDGFR $\beta$ signaling pathway is involved in pericyte survival and subsequent development as well as the function of the BBB during adulthood and senescence, as demonstrated by experiments in pericyte-deficient mice [17,38]. In addition to its role as a marker of CNS pericytes, PDGFR $\beta$ is expressed in oligodendrocyte precursor cell (OPC)/neuron-glial antigen 2 (NG2) parenchymal glial cells [2,25,42]. Other markers for pericytes exist (Table 1), but these remain inconclusive. Anatomical studies are required to investigate the characteristics of pericytes that possess longitudinal processes along vessels and contribute to BBB maintenance [15]. Pericytes in the brain are highly heterogeneous and have different morphologies as well as functions depending on their location in the vasculature [10]. Further, transgenic mice generated to study pericyte function may yield information on other cell types [43]. Therefore, "peripheral blood-specific" markers must 
be used with caution [44]. Although there is no scientific consensus on what constitutes true pericytes [45], the current review focuses on studies using definitive pericyte-related markers and anatomy.

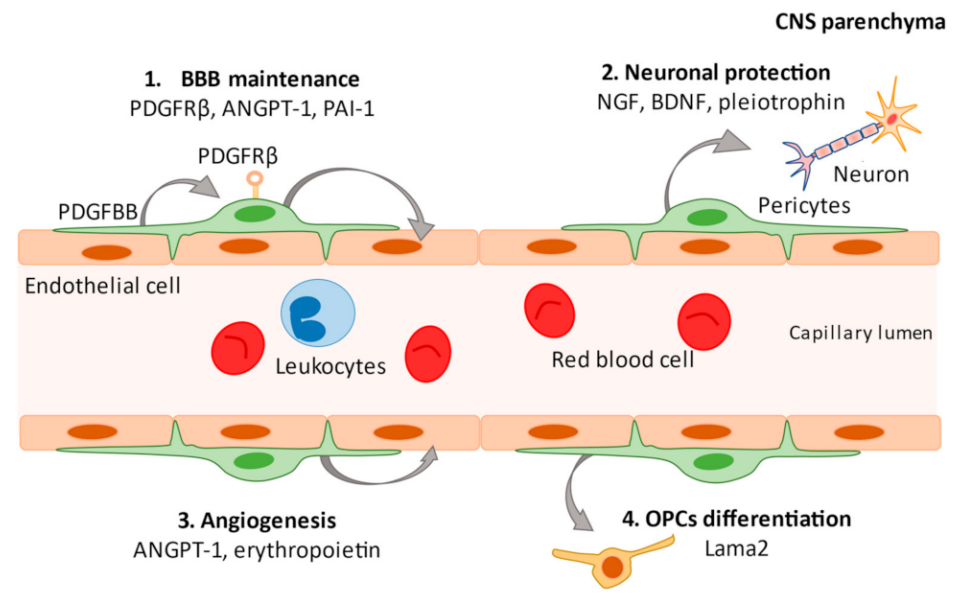

Figure 1. Regulatory functions of pericytes. In the central nervous system (CNS), platelet-derived growth factor-beta subunit (PDGF-BB) is released by endothelial cells and binds to PDGFR $\beta$ at the cell surface of pericytes to promote pericyte vascularization within the blood-brain barrier (BBB). Secretion of angiopoietin-1 (ANGPT-1) and plasminogen activator inhibitor type 1 (PAI-1) from pericytes promotes the development of vascular endothelial cells and contributes to the maintenance of the BBB (1). Pericytes maintain neuronal health by secreting factors such as nerve growth factor (NGF), brain-derived nerve growth factor (BDNF), and pleiotrophin (2). Pericytes are involved in angiogenesis by secreting ANGPT-1 and erythropoietin (3) and produce a factor (Lama2) that facilitates the differentiation of oligodendrocyte progenitor cells (OPCs) into mature oligodendrocytes (4).

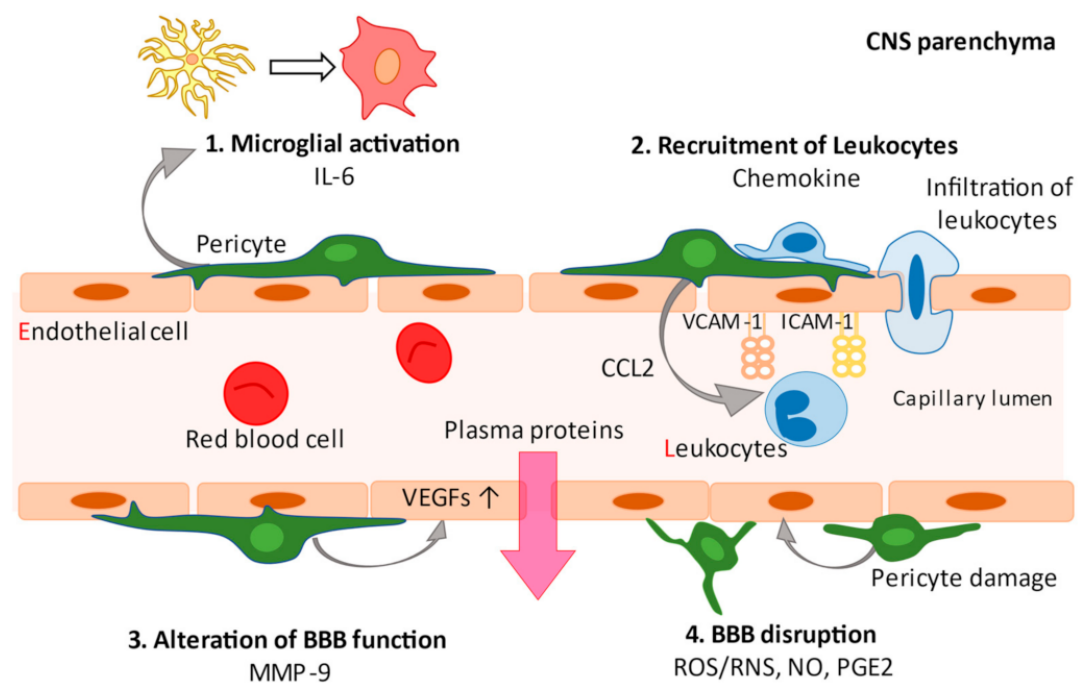

Figure 2. In pathological conditions, pericytes generate various inflammatory factors. Pericytes secrete IL-6 that can polarize parenchymal microglia to a proinflammatory phenotype to activate microglia (1). The secretion of chemokines (CCL2, CXCL1, CXCL8, and CXCL10) by pericytes recruits leukocytes to the CNS parenchyma via the upregulation of ICAM- 1 and VCAM- 1 adhesion molecules on the endothelium (2). MMP-9 secretion stimulates the production and secretion of vascular endothelial growth factor (VEGF), resulting in endothelial dysfunction (3). Secretion of reactive oxygen species/reactive nitrogen species (ROS/RNS), nitric oxide (NO), and prostaglandins (PGE2) by pericytes lead to vasodilation and breaching of the blood-brain barrier. Pericytes themselves are morphologically altered by inflammatory mediators (4). 
Table 1. Common markers used to identify pericytes in the central nervous system of mice that also label other cell types.

\begin{tabular}{|c|c|c|c|}
\hline Marker & Cells Labeled & Main Function & Reference(s) \\
\hline $\begin{array}{c}\text { PDGFR } \beta \\
\text { (platelet-derived growth factor receptor beta) }\end{array}$ & Fibroblasts, SMCs, pericytes & Tyrosine kinase receptor & {$[14,41]$} \\
\hline $\begin{array}{c}\text { NG2 } \\
\text { (CSPG4; chondroitin sulfate proteoglycan 4) }\end{array}$ & OPCs, NSCs, SMCs, pericytes & Cell-membrane proteoglycan & [46] \\
\hline $\begin{array}{c}\text { CD13 } \\
\text { (aminopeptidase } \mathrm{N} \text { ) }\end{array}$ & Fibroblasts, SMCs, pericytes & Cell-membrane aminopeptidase & [14] \\
\hline $\begin{array}{c}\alpha \mathrm{SMA} \\
\text { (actin, aortic smooth muscle) }\end{array}$ & SMCs, myofibroblasts, pericytes & Cytoskeletal protein & [14] \\
\hline Desmin & SMCs, pericytes & Intermediate filament & [14] \\
\hline $\begin{array}{c}\text { Rgs5 } \\
\text { (regulator of G protein signaling 5) }\end{array}$ & SMCs, pericytes & Regulator of $G$ protein & [47] \\
\hline $\begin{array}{c}\text { CD146 } \\
\text { (cell surface glycoprotein MUC18) }\end{array}$ & SMCs, pericytes & Membrane proteins & [48] \\
\hline $\begin{array}{c}\text { SUR2 } \\
\text { (sulfonylurea receptor 2) }\end{array}$ & SMCs, pericytes & Potassium-channel & {$[47,49]$} \\
\hline $\begin{array}{c}\text { Kir6.1 } \\
(\mathrm{K}+\text { channel pore-forming subunit })\end{array}$ & SMCs, fibroblasts, pericytes & Potassium-channel & {$[47,49]$} \\
\hline $\begin{array}{c}\text { NeuroTrace } 500 / 525 \\
\text { (fluorescent Nissl dye/FluoroNissl Green) }\end{array}$ & Pericytes & - & [50] \\
\hline Vitronectin & SMCs, Pericytes & Complement-binding protein & {$[49,51]$} \\
\hline
\end{tabular}

Note: NSCs, neural stem cells; OPCs, oligodendrocyte progenitor cells; SMCs, smooth muscle cells.

\section{Pericytes and Neuroinflammation}

Evidence accumulated from experimental models and human samples implicates immunological processes in the pathogenesis of epilepsy [1,4]. The involvement of pericytes in the CNS immune responses has attracted significant attention. Pericytes present heterogeneous signals to the surrounding cells and actively modulate inflammatory responses in a tissue- and context-dependent manner. The expression of various pattern-recognition receptors (PRRs), including toll-like receptors (TLRs) and nucleotide-binding and oligomerization domain (NOD)-like receptor families, has been detected in brain pericytes [52]. Given the abundance of surface receptors, pericytes can respond to inflammatory mediators, such as monocyte chemoattractant protein-1 (MCP-1/CCL2) and tumor necrosis factor (TNF)- $\alpha$, which in turn induce the secretion of CCL2, nitric oxide (NO), and several cytokines $[7-9,53]$. Pericytes act as promoters of both the innate and adaptive immune system [43]. In the CNS, microglia are a hallmark of the immune response, which produce cytokines such as interleukin (IL)-1 $\beta$, TNF- $\alpha$, IL-6, and various other chemokines [54], and related effector pathways, including cyclooxygenase-2 (COX-2)/prostaglandin (PGE2) and complement factors [55]. The rapid activation of microglia impairs neuronal function by inducing inflammatory mediators, such as NO, reactive oxygen species (ROS), and proinflammatory cytokines $[56,57]$.

Pericytes have been shown to be more sensitive to proinflammatory cytokines compared to other cells in the NVU [9,11-13]. Specifically, cytokine and chemokine release profiles from brain pericytes in response to TNF- $\alpha$ are distinct to those of other cell types comprising the NVU, and TNF- $\alpha$-stimulated pericytes release macrophage inflammatory protein (MIP)- $1 \alpha$ and IL-6. Among BBB cells, pericytes stimulated with TNF- $\alpha$ induced the highest levels of $i N O S$ and IL- $1 \beta$ mRNA expression, which indicates the activation of BV-2 microglia [9]. The mechanism underlying TNF- $\alpha$-induced IL-6 release involves the inhibitor kappa B (IкB)-nuclear factor kappa-light-chain-enhancer of activated B cells $(\mathrm{NF} \kappa \mathrm{B})$ and the Janus family of tyrosine kinase (JAK)-signal transducer and activator of transcription (STAT) 3 pathways [13]. NFkB plays a key role in inflammation, immune, and stress-related responses, as well as in the regulation of cell survival and in the growth of neural processes in developing peripheral and central neurons [58]. These findings indicate that the activated brain pericytes trigger the development of uncoordinated NVU function, including glial activation, and may act as sensors at the BBB in TNF- $\alpha$-mediated brain inflammation. 
Pericytes also release anti-inflammatory factors, highlighting their involvement in regeneration and protection $[7,59,60]$. Pericytes respond to lipopolysaccharide (LPS), secrete anti-inflammatory cytokines such as IL-10 and IL-13 [61], and produce neurotrophins such as nerve growth factor (NGF) and brain-derived neurotrophic factor (BDNF), which regulate neuronal development [42,62]. Pericytes upregulate neurotrophin-3 production in response to hypoxia, resulting in increased NGF production in astrocytes, thereby protecting neurons from hypoxia-induced apoptosis [62]. These actions highlight the neuroprotective functions of pericytes under pathological conditions.

\section{Pericytes and Epilepsy}

Table 2 summarizes the research on pericytes and epilepsy.

Table 2. Research and key findings on pericytes and epilepsy.

\begin{tabular}{|c|c|c|c|c|}
\hline No. & Patients/Model & Species & Key Findings & Reference \\
\hline 1 & Intractable complex partial seizures & Humans & $\begin{array}{l}\text { Degeneration of pericytes (aggregates of } \\
\text { cellular debris within the basement } \\
\text { membrane) with the morphological changes } \\
\text { in pericyte-basement membrane unit } \\
\text { thickness and pericyte cytoplasmic density } \\
\text { were observed in the spiking area of } \\
\text { microvessels in an electron microscopy study } \\
\text { of brain tissue }\end{array}$ & {$[63]$} \\
\hline \multirow[b]{2}{*}{2} & TLE with HS & Humans & $\begin{array}{l}\text { PDGFR } \beta+\text { cells are distributed around the } \\
\text { cerebrovasculature and are present in the } \\
\text { brain parenchyma of human TLE specimens }\end{array}$ & \multirow[b]{2}{*}{ [2] } \\
\hline & $\begin{array}{l}\text { NG2DsRed or C57BL/6J mice } \\
\text { (intraperitoneal KA injections) }\end{array}$ & Mice & $\begin{array}{l}\text { - Constitutive cerebrovascular NG2DsRed } \\
\text { pericyte coverage is impaired in response to } \\
\text { SE in vivo or seizure-like events in vitro } \\
\text { Redistribution of parenchymal and vascular } \\
\text { PDGFR } \beta \text { + cells occurs in vitro and in vivo } \\
\text { Vascular and parenchymal PDGFR } \beta \text { + cells } \\
\text { partially co-localize with NG2DsRed and } \\
\text { NG2, but not with IBA-1 (indicators } \\
\text { of microglia) }\end{array}$ & \\
\hline \multirow[t]{2}{*}{3} & $\begin{array}{l}\text { FCD, TLE without HS, } \\
\text { cryptogenic epilepsy }\end{array}$ & Humans & $\begin{array}{l}\text { - FCD and TLE-HS display the highest } \\
\text { PDGFR } \beta \text { immunoreactivity at the } \\
\text { microvasculature identifying pericytes } \\
\text { Cryptogenic epilepsy patients also showed a } \\
\text { similar immune response pattern, although to } \\
\text { a lesser extent than that in FCD } \\
\text { The amount of perivascular PDGFR } \beta \\
\text { immunoreactivity was found to be associated } \\
\text { with increased hippocampal angiogenesis in } \\
\text { tissues from patients with TLE-HS }\end{array}$ & \multirow[t]{2}{*}[25]{} \\
\hline & $\begin{array}{l}\text { Neurovascular dysplasia rat model } \\
\text { (Sprague-Dawley rats with pre-natal } \\
\text { exposure to methyl-axozy methanoic } \\
\text { acid), pilocarpine }\end{array}$ & Mice & $\begin{array}{l}\text { - Pericyte-vascular dysplasia was detected in } \\
\text { hippocampi corresponding to } \\
\text { neuronal heterotopias } \\
\text { - } \\
\text { Severe SE was associated with a } \\
\text { region-specific increase in } \\
\text { PDGFR } \beta \text { immunoreactivity }\end{array}$ & \\
\hline 4 & TLE & Humans & $\begin{array}{l}\text { - Chronic IFN- } \gamma \text { treatment blocks signaling } \\
\text { through PDGFR } \beta \text { by enhancing agonist } \\
\text { PDGF-BB }\end{array}$ & {$[26]$} \\
\hline 5 & $\begin{array}{l}\text { Drug-resistant TLE } \\
\text { (microarray analysis) }\end{array}$ & human & $\begin{array}{l}\text { - TGF } \beta 1 \text { decreased pericyte proliferation and } \\
\text { decreased phagocytosis } \\
\text { TGF } \beta 1 \text { also upregulates the expression of } \\
\text { IL-6, MMP-2, and NOX4, which disrupt the } \\
\text { function of the BBB, and these responses to } \\
\text { TGF } \beta 1 \text { may not be therapeutic for the } \\
\text { neurovascular system }\end{array}$ & {$[27]$} \\
\hline
\end{tabular}


Table 2. Cont.

\begin{tabular}{|c|c|c|c|c|}
\hline No. & Patients/Model & Species & Key Findings & Reference \\
\hline 6 & $\begin{array}{l}\text { Dynamics of NG2 mural cells under SE } \\
\text { with systemic KA injection in mice }\end{array}$ & Mice & $\begin{array}{l}\text { - NG2 mural cells are added and removed from } \\
\text { veins, arterioles, and capillaries after } \\
\text { status epilepticus } \\
\text { Loss of NG2 mural cells is proportional to } \\
\text { seizure severity and vascular pathology (e.g., } \\
\text { rigidity, perfusion, and permeability) } \\
\text { Treatment with PDGF-BB reduced NG2 mural } \\
\text { cell loss, vascular pathology, and epileptiform } \\
\text { electroencephalogram activity }\end{array}$ & [28] \\
\hline
\end{tabular}

- $\quad$ Pericyte-microglia assemblies with

IBA1/HLA microglial cells outlining the

capillary wall were observed in TLE-HS and

$\begin{array}{lll}\text { TLE with or without HS, FCD Humans } & \text { FCD-Ilb specimens } \\ & \bullet \quad \text { Proinflammatory cytokines such as IL-1 } \beta\end{array}$

7 cause morphological changes and IL-6 causes cell damage in human-derived pericytes

NG2DsRed/C57BL6 (unilateral

NG2DsRed/C57BL6 (unilateral
intra-hippocampal KA injections)
NG2DsRed/C57BL6 (unilateral intra-hippocampal KA injections)
Mice low $-\mathrm{Mg}^{2+}$ conditions)
- $\quad$ IL-1 $\beta$ elicited pericyte morphological changes and pericyte-microglia clustering in NG2DsRed hippocampal slices

- Multicellular scarring occurs at the outer capillary wall in the hippocampus during seizure progression

- $\quad$ PDGFR $\beta$ stromal cells and collagens III and IV participate in the localized pericyte-glial scarring and capillary pathology in hippocampal subregions

- $\quad$ PDGFR $\beta$ is a proposed anti-inflammatory entry point for chronic disease stages in vivo

- $\quad$ Pericytes regulate changes in vascular diameter in response to neuronal activity

- $\quad$ Recurrent seizures are associated with impaired neurovascular coupling and increased BBB permeability in capillaries

- $\quad$ Recurrent seizures lead to depolarization of pericytic mitochondria and subsequent vasoconstriction

- $\quad$ PDGFR $\beta$ levels were increased from $1 \mathrm{~h}$ to 4 days after CCI in the injured ipsilateral hippocampus prior to increased expression of markers of microglia and astrocytes; this

Traumatic brain injury mode (C57BL/6J mice with CCI and pilocarpine injections)

Mice supports the postulated role of pericytes as initiators of the CNS immune response

- Treatment with imatinib on postoperative days $0-4$ reduced seizure susceptibility, demonstrating the usefulness of imatinib in vitro

\section{Blood-Brain Barrier Disruption in the Pathogenesis of Epilepsy}

Experimental evidence of BBB impairment in the pathogenesis of epilepsy has been demonstrated in patients and animal models [64-67], which is a hallmark of epilepsy. BBB disruption can also directly induce seizure activity and exacerbate epileptogenesis; the relationship between epilepsy and BBB breakdown is bidirectional [64,65].

BBB dysfunction and subsequent infiltration of serum albumin into the brain leads to changes in epileptogenesis, including astrocyte changes, neuroinflammation, excitatory synapse formation, and pathological plasticity $[68,69]$. These BBB alterations are not only due to leakage, as demonstrated by Evans Blue staining [65]. There is involvement of various inflammatory mediators as nondisruptive changes at the molecular level of pericytes are also involved in the changes of the BBB; specifically, they secrete various mediators as 
follows: IL-1 $\beta$, TNF- $\alpha$, IFN- $\gamma$, matrix metalloproteinases (MMPs), ROS/reactive nitrogen species (RNS), (NO), and prostaglandin E2 (PGE2). Pericyte-derived MMP-9 upregulation in the cerebral microvasculature can cause endothelial dysfunction through degradation of tight junctions and extracellular matrices, resulting in subsequent pericyte loss from the microvasculature and BBB disruption [11,43]. Moreover, the secretion of ROS/RNS, NO, and PGE2 lead to vasodilation and breaching of the BBB [9]. Epileptic seizures can cause pericytes surrounding the blood vessels to rearrange [2] and morphologically alter, which is facilitated by the inflammatory mediators $[29,30]$. These series of alterations are thought to be linked to the pathogenesis of epilepsy, although further details are warranted.

\section{Leukocyte Recruitment and Peripheral-to-Central Infiltration}

Pericytes regulate the migration of leukocytes across the BMVEC barrier and secrete key molecules that support the BBB $[17,18]$. Chemokines (CCL2, CXCL1, CXCL8, and CXCL10) secreted by pericytes in both basal and inflammatory states recruit peripheral immune cells, including monocytes, B and T cells, and neutrophils, to the CNS parenchyma via upregulation of intercellular adhesion molecule-1 (ICAM-1) and vascular cell adhesion molecule-1 (VCAM-1) on the endothelium [7-9,70]. Although the human brain is considered an immune-privileged area $[68,71]$, this is not preserved during inflammatory conditions. Analysis of brain parenchyma in patients with epilepsy showed that there have been both positive [72,73] and negative [74] reports on the occurrence of infiltration of peripheral leukocytes into the brain tissue. Recent experimental research demonstrated that peripheral-to-CNS cell infiltration, particularly monocytes, occurs in the status epilepticus (SE) model, without evidence of infections or immune disorders $[20,75,76]$. The possibility of classifying peripheral monocytes and indigenous microglia, which have been considered difficult to differentiate, has been increased using genetic engineering $[75,77,78]$.

In chemokine receptor 2 (CCR2)-knockout mice, the CCL2 receptor, which blocks peripheral monocyte invasion into the brain tissue, attenuated neuronal damage in SE models [75]. Analysis of the brain tissue from pediatric patients with drug-resistant epilepsy (DRE) revealed that seizure frequency was correlated with the number of infiltrating peripherally activated CD3+ T cells and monocytes, but not microglia [19]. Current analysis of pediatric patients with DRE also demonstrated a correlation between the number of seizures and intracellular IL-1 $\beta$ levels in monocytes [79], while experimental data and human research attributed seizure-induced neuronal death to the activation of resident microglia $[78,80]$. Whether the peripheral monocytes or the resident microglia are the primary triggers of epilepsy, as well as the extent to which the infiltrated cells are significant, remains to be determined; nevertheless, the combination of the roles of the pericytes in maintaining the BBB integrity, producing inflammatory mediators, and recruiting leukocytes indicate that the pericytes could be intimately involved in the pathogenesis of epilepsy.

\section{Clinical Evidence Links Pericytes to Epilepsy}

The disarray of the pericyte-basal lamina interface in patients with epilepsy was first described in 1990 [63]. Evidence of pericyte degeneration with basement membrane unit thickness and cytoplasmic density has also been reported in most of the spiking area microvessels in human brain tissues of intractable complex partial seizures using an electron microscope [63].

With the advent of PDGFR $\beta$, though a nonspecific CNS pericyte marker, the immunostaining reports of the presence of PDGFR $\beta+$ cells have emerged in the brain specimens of patients with intractable epilepsy in focal cortical dysplasia (FCD) and temporal lobe seizures (TLE) $[2,25,29]$. In tissues from patients with refractory TLE and hippocampal sclerosis (HS), the presence of PDGFR $\beta$ + cells associated with blood vessels and parenchyma was observed, although findings were heterogenous [2]. Indeed, the highest perivascular PDGFR $\beta$ immunoreactivity was detected in patients with TLE-HS, specifically in the microvasculature [2]. Tissue from patients with cryptogenic epilepsy has exhibited a similar immune response pattern, although to a lesser extent than that of FCD. Increased perivascu- 
lar PDGFR $\beta$ immunoreactivity was associated with increased hippocampal vascularization in the cells of patients with TLE-HS [25].

Another study of TLE and FCD specimens revealed robust PDGFR $\beta$-positive cell pericyte immunoreactivity surrounding the blood vessels, particularly in TLE with HS specimens, with aggregation of IBA1/HLA microglial cells and pericyte-microglia outlining the capillary wall [29]. The morphological changes in pericytes were induced by proinflammatory cytokines, including IL- $1 \beta, \mathrm{TNF} \alpha$, and IL-6; in particular, IL-6 exposure was drastically associated with apoptosis, suggesting pericyte damage [29].

Collectively, the accumulation of pericytes (PDGFR $\beta$-positive cells) in the cerebral vascular regions was consistently observed in patients with refractory epilepsy $[2,25,29]$. The degree of accumulation correlates to some extent with the clinical picture [25,29], and morphological changes of the pericytes might be due to proinflammatory cytokines [29]. In addition, the amount of angiogenesis, which is associated with epileptogenesis, was related to the number of PDGFR $\beta$-positive cells [25], suggesting a relationship between PDGFR $\beta$-positive cells and the pathogenesis of epilepsy.

\section{Experimental Evidence Links Pericytes to Epilepsy}

An in vivo study of NG2DsRed mice, which enabled the visualization of cerebrovascular pericytes, revealed heterogeneous perivascular prominence of NG2DsRed cells with PDGFR $\beta$ expression in an SE model induced by intraperitoneal kainic acid (KA) [2]. These heterogeneous perivascular patterns of PDGFR $\beta+$ cells are inconsistent with the aforementioned human tissue findings [2,25,29], which have also been observed in a rat model of neurovascular dysplasia SE, particularly in the hippocampus with a neurovascular dysplasia SE rat model [25].

An in vitro and in vivo study by Milesi et al. demonstrated that the parenchymal and vascular PDGFR $\beta$ + cells were redistributed, alongside partial colocalization of vascular and parenchymal PDGFR $\beta$ + cells with NG2DsRed and NG2, but not with IBA-1 [2]. These findings, suggesting that the accumulation of pericytes and microglia is associated with epileptic seizure events, have been documented in recent studies $[29,30]$.

Klement et al. employed a model of TLE (associated with HS) in NG2DsRed mice to assess the impact of seizure progression on capillary pericytes and surrounding glial cells [29]. In vivo, SE mice presenting with spontaneous recurrent seizures (SRS) exhibited disorganized NG2DsRed-positive pericyte somata in the hippocampus at $72 \mathrm{~h}$ and 1 week after SE (epileptogenesis) in the hippocampus. Pericyte modifications clustered with IBA1-positive microglia, surrounding capillaries, and overlapped topographically with pericytes lodged within microglial cells [29]. Residual microglial clustering was also observed surrounding NG2DsRed pericytes in SRS, proinflammatory mediators, such as IL- $1 \beta$, IL- 6 , TNF- $\alpha$, and particularly IL- $1 \beta$; however, the in vitro study in humans revealed that IL-6 induced these morphological changes of pericyte-microglia clustering in NG2DsRed hippocampal slices [29]. In addition, Klement et al. also reported a pericyte-glia perivascular scar with capillary leaks in the hippocampus during seizure activity. These scars in the cornu ammonis region developed an abnormal distribution or accumulation of extracellular matrix collagen III/IV as the seizure progressed [30]. In vitro experiments induced by 4 -aminopyridine and low- $\mathrm{Mg}^{2+}$ conditions repeated seizures that cause vasoconstriction associated with the depolarization of mitochondria in pericytes and gradual neurovascular disconnection, suggesting that the pericyte damage causes vascular dysfunction in epilepsy [31]. The gradual progression of neurovascular decoupling during recurrent seizures suggests that pericyte damage induces vascular dysfunction in epilepsy (Figure 3) [31]. 


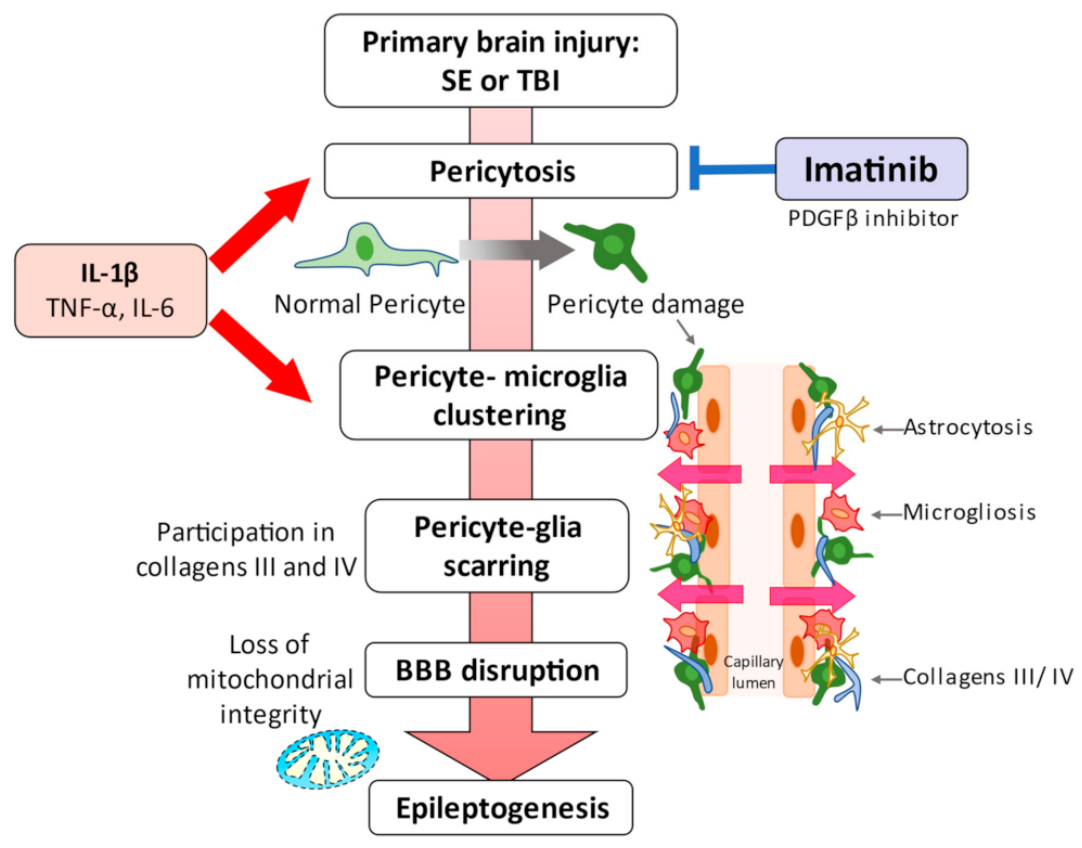

Figure 3. Schematic representation of the events linking pericytes to epilepsy. Status epilepticus leads to redistribution and remodeling of cerebrovascular pericytes, potentially contributing to blood-brain barrier permeability $[2,28,29]$. A significant clustering of microglia/macrophages around pericytes occurs one week after the attack, although pericyte proliferation is significantly increased as early as $72 \mathrm{~h}$ [29]. These series of pericyte-related modifications are promoted by proinflammatory cytokines, including IL- $1 \beta, \mathrm{TNF} \alpha$, and IL- 6 . Alterations caused by IL- $1 \beta$, which is one of the cytokines most deeply involved in the pathogenesis of epilepsy, were most pronounced. These pericyte-associated modifications and pericyte-microglia clustering may be facilitated by IL-1 $\beta$ [29], and pericyte-glial scarring with collagens III and IV process leaky capillaries during seizure progression [30]. Recurrent seizures can lead to pericytic injury with neurovascular decoupling and BBB dysfunction at the arterial and capillary levels. Moreover, capillary vasoconstriction is accompanied by a loss of mitochondrial integrity in pericytes [81]. In vitro and in vivo studies have highlighted the potential of pericytes as a therapeutic target for seizure disorders [28,30,32].

\section{Prospects for Pericyte-Mediated Epilepsy Therapy}

PDGFR $\beta$ can regulate pericyte survival, proliferation, and migration signals and is commonly used as a marker for pericytes [40]; PDGFR $\beta$ suppression has been proposed as a possible treatment for epilepsy [28,30,32].

As described above, a pericyte-glia perivascular scar with capillary leaks induced by seizures and a high expression of PDGFR $\beta$ transcript and protein levels were detected [30]. In the organotypic hippocampal cultures, PDGFR $\beta$ reactivity surrounding capillaries is also enhanced by electrographic activity and was reduced by PDGF-BB (a PDGFR $\beta$ agonist) and PDGF $\beta$ inhibitor imatinib [30]. Furthermore, PDGF-BB can reduce mural cell loss, vascular pathology, and epileptiform electroencephalography activity in a KA-induced SE model [28]. Recently, traumatic brain injury (TBI) has been highlighted as a major factor in epilepsy owing to certain intractable cases. The evaluation of the involvement of pericytes in the pathogenesis of epilepsy was performed using a controlled cortical impact (CCI) device. PDGFR $\beta$ levels were significantly increased following CCI in the injured ipsilateral hippocampus; pilocarpine-induced seizures can be regulated by imatinib treatment in this CCI model [32]. The efficacy of imatinib was also observed in vitro.

The findings from both in vitro and in vivo studies highlight the potential of pericytes as a therapeutic target for seizure disorders, as indicated by the efficacy of PDGF-BB and imatinib in blocking PDGFR $\beta$. However, both PDGFR $\beta$ and PDGF-BB are required for the pericyte coating of the BBB in the developing CNS [38,41]. Under pathological conditions, 
mural cells in the immediate postacute phase (SE, ischemic stroke, and head trauma) require support from the PDGFR $\beta$ activation [28]; hence, the inflammatory involvement of PDGFR $\beta$ may be relevant in long-term progression as well as in chronic stages.

When considering the pharmacological modulation of pericyte signaling pathways as a means of attenuating disease progression and capillary pathology, the impact of pericyte modulation in the epileptic brain must consider the activation state of the glial cells and the disease stage (e.g., acute vs. chronic) [29]. Further, considering the distinct functions of PDGFR $\beta$ at different developmental stages, the timing of PDGFR $\beta$ inhibition needs to be carefully studied; moreover, avoiding imatinib in the acute phase of the disease may be considered. It remains debatable whether the changes in pericytes and accumulation of microglia associated with PDGFR expression in this series of studies should be suppressed.

Transforming growth factor-beta 1 (TGF $\beta 1$ ) is a multifaceted cytokine in the brain that plays a role in regulating cell proliferation, differentiation, survival, and scar formation $[82,83]$. Since 1989, the possibility of PDGF-induced TGF- $\beta$ signaling has been suggested [84]; PDGFR- $\beta$ and TGF- $\beta$ with PDGFR- $\beta$ might mediate the endothelial cell/pericyte interaction to protect the BBB integrity [33]. The potential involvement of TGF- $\beta$ in epileptogenesis has been recognized from an experimental model showing TGF- $\beta$ upregulation as part of the inflammatory response [85]. Microarray analysis of TGF 31 -stimulated human brain pericytes isolated from intractable TLE demonstrated inhibition of pericyte proliferation and phagocytosis by TGF $\beta 1$ [27]. However, TGF $\beta 1$ also enhanced the expression of IL-6, MMP-2, and NOX4, which can disrupt BBB functioning; thus, these reactions caused by TGF $\beta 1$ might not lead to the treatment of the neurovascular system [27].

Although the brain pericyte-derived TGF- $\beta$ contributes to the upregulation of BBB functions [86], suppression of TGF $\beta 1$ indicates improvement in epilepsy [87]. Losartan, an angiotensin-type 1 receptor (AT1) antagonist, prevents phosphorylation of Smad proteins of TGF- $\beta$ signaling $[88,89]$, which has demonstrated both neuroprotective and antineuroinflammatory effects [90-92].

These in vitro studies also suggest that human-derived pericytes are morphologically altered by proinflammatory cytokines that induce apoptosis [29], indicating the potential of targeting IFN- $\gamma$ for pericyte-mediated epilepsy treatment [26]. IFN- $\gamma$ is a central component of the CNS inflammatory response and is secreted by microglia, astrocytes, endothelial cells, and circulating immune cells [93-95]. This classical inflammatory mediator has been implicated in CNS diseases, including epilepsy [96,97]. Altering the proportion of microglial phenotypes via IFN- $\gamma$ treatment improved the prognosis in a mouse model of epilepsy [98].

Notably, in epileptiform conditions, IL-1 $\beta$, a neurotoxic cytokine and one of the cytokines chiefly involved in the pathogenesis of epilepsy, prominently contributes to the morphological changes in the pericytes [29]. There is evidence that the IL-1/IL-1R1 axis plays an important role in the inflammatory response in epilepsy, as presented by Vezzani et al. in an excellent review [4,99]. IL-1 $\beta$ agonist, the IL-1 receptor antagonist (IL-1RA), has already been tested for clinical application for epileptic syndromes using anakinra, and has shown favorable clinical outcomes [100-103]. The use of anakinra on pericytes in status epilepticus has not yet been investigated. To ensure the involvement of pericytes in epilepsy, it is worthwhile to confirm that anakinra suppresses the morphological changes in pericytes and reduces seizures.

Previous reports have demonstrated that inhibition of pericytes could have positive effects of neuroprotection [26,28,30,32]; however, there is also a concern that the suppression of pericytes by TGF $\beta 1$ may not necessarily have a positive effect on the CNS [27]. Since TGF $\beta 1$ suppresses pericyte phagocytosis and reduces the expression of central leukocyte trafficking chemokines and adhesion molecules while increasing the expression of proinflammatory cytokines and enzymes that promote BBB disruption, a paradoxical reaction has been reported [27]. The TGF $\beta 1$ response of pericytes may differ from the 
anti-inflammatory response of microglia [104-107]; therefore, further studies are required to obtain any effect on this nonuniform response.

In the pathogenesis of epilepsy, pericytes adopt a phenotype that is neither solely pro- nor anti-inflammatory [27]. Merely suppressing pericytes may not be sufficient to improve the treatment of epilepsy, and it may be necessary to seek a treatment tailored to the affected child in combination with various therapies that have been introduced in recent reviews [108].

\section{Conclusions}

In this review, we present evidence for the substantive role of pericytes in the pathogenesis of epilepsy. The roles of pericytes in maintaining BBB integrity, producing inflammatory secretions, and recruiting leukocytes highlights the potential role of pericytes in the pathogenesis of epilepsy. Pericytes may also act as sensors of inflammatory processes in the CNS and regulating them may lead to the development of novel therapies for epilepsy. However, as there remains a lack of absolute molecular markers for pericytes, and since pericytes originate from multiple cellular sources and vary in morphology, localization as well as function in different tissues leaves several issues to be addressed. In addition, we are unable to determine whether brain inflammation is an initiator or a consequence of a systemic inflammatory process.

Several reports have suggested entry points that may also act as a basis for various neurovascular therapies, including anakinra $[100,101]$ and losartan [87], though the level of evidence for both drugs is limited for the establishment of treatment for epilepsy. These drugs provide an avenue for novel therapeutic, anti-inflammatory, or cerebrovascular repair to mitigate epileptic pathophysiology. Unfortunately, definitive treatments for epilepsy are currently lacking. BBB integrity and systemic peripheral inflammation may contribute to epilepsy and hold potential for molecular biomarkers and targets in the treatment of epilepsy. Moreover, human pluripotent stem cell-derived brain pericyte-like cells induced BBB properties in BMECs, resulting in strengthening of the barrier and a reduction in transcytosis [109]. These stem cell techniques could be applied to examine the possibility of new strategies to selectively target pericytes and the role of pericytes in epilepsy more specifically. Novel tools to control pericytes should be developed to target inflammatory vascular-related processes during seizure progression or activity.

Author Contributions: Conceptualization, G.Y.; investigation, K.K. and S.M.; writing—original draft preparation, G.Y.; writing-review and editing, F.T.; visualization, S.D.; supervision, Y.K. and H.K. All authors have read and agreed to the published version of the manuscript.

Funding: This study was funded by the Kawano Masanori Memorial Foundation for Promotion of Pediatrics in Japan under grant number 30-7 and the Japan Epilepsy Research Foundation under grant number 20012. APC funded by the Japan Epilepsy Research Foundation.

Institutional Review Board Statement: We confirm that we have read the journal's position on the issues associated with ethical publication and affirm that this report is consistent with these guidelines.

Informed Consent Statement: Not applicable.

Data Availability Statement: The datasets generated and/or analyzed during the current study are available at the PubMed database repository (https:/ / pubmed.ncbi.nlm.nih.gov/, accessed on 31 May 2021).

Conflicts of Interest: The authors declare no conflict of interest.

\section{References}

1. Vezzani, A.; Balosso, S.; Ravizza, T. The role of cytokines in the pathophysiology of epilepsy. Brain. Behav. Immun. 2008, 22, 797-803. [CrossRef] [PubMed]

2. Milesi, S.; Boussadia, B.; Plaud, C.; Catteau, M.; Rousset, M.C.; De Bock, F.; Schaeffer, M.; Lerner-Natoli, M.; Rigau, V.; Marchi, N. Redistribution of PDGFR $\beta$ cells and NG2DsRed pericytes at the cerebrovasculature after status epilepticus. Neurobiol. Dis. 2014, 71, 151-158. [CrossRef] 
3. Marchi, N.; Banjara, M.; Janigro, D. Blood-brain barrier, bulk flow, and interstitial clearance in epilepsy. J. Neurosci. Methods 2016, 260, 118-124. [CrossRef]

4. Vezzani, A.; Balosso, S.; Ravizza, T. Neuroinflammatory pathways as treatment targets and biomarkers in epilepsy. Nat. Rev. Neurol. 2019, 15, 459-472. [CrossRef] [PubMed]

5. Löscher, W.; Friedman, A. Structural, Molecular, and Functional Alterations of the Blood-Brain Barrier during Epileptogenesis and Epilepsy: A Cause, Consequence, or Both? Int. J. Mol. Sci. 2020, 21, 591. [CrossRef]

6. Nishibori, M.; Wang, D.; Ousaka, D.; Wake, H. High Mobility Group Box-1 and Blood-Brain Barrier Disruption. Cells 2020, 9 , 2650. [CrossRef] [PubMed]

7. Kovac, A.; Erickson, M.A.; Banks, W.A. Brain microvascular pericytes are immunoactive in culture: Cytokine, chemokine, nitric oxide, and LRP-1 expression in response to lipopolysaccharide. J. Neuroinflamm. 2011, 8, 139. [CrossRef] [PubMed]

8. Jansson, D.; Rustenhoven, J.; Feng, S.; Hurley, D.; Oldfield, R.L.; Bergin, P.S.; Mee, E.W.; Faull, R.L.; Dragunow, M. A role for human brain pericytes in neuroinflammation. J. Neuroinflamm. 2014, 11, 104. [CrossRef] [PubMed]

9. Matsumoto, J.; Takata, F.; Machida, T.; Takahashi, H.; Soejima, Y.; Funakoshi, M.; Futagami, K.; Yamauchi, A.; Dohgu, S.; Kataoka, Y. Tumor necrosis factor- $\alpha$-stimulated brain pericytes possess a unique cytokine and chemokine release profile and enhance microglial activation. Neurosci. Lett. 2014, 578, 133-138. [CrossRef] [PubMed]

10. Rustenhoven, J.; Jansson, D.; Smyth, L.C.; Dragunow, M. Brain Pericytes as Mediators of Neuroinflammation. Trends Pharmacol. Sci. 2017, 38, 291-304. [CrossRef]

11. Takata, F.; Dohgu, S.; Matsumoto, J.; Takahashi, H.; Machida, T.; Wakigawa, T.; Harada, E.; Miyaji, H.; Koga, M.; Nishioku, T.; et al. Brain pericytes among cells constituting the blood-brain barrier are highly sensitive to tumor necrosis factor- $\alpha$, releasing matrix metalloproteinase-9 and migrating in vitro. J. Neuroinflamm. 2011, 8, 106. [CrossRef]

12. Machida, T.; Takata, F.; Matsumoto, J.; Takenoshita, H.; Kimura, I.; Yamauchi, A.; Dohgu, S.; Kataoka, Y. Brain pericytes are the most thrombin-sensitive matrix metalloproteinase-9-releasing cell type constituting the blood-brain barrier in vitro. Neurosci. Lett. 2015, 599, 109-114. [CrossRef]

13. Matsumoto, J.; Dohgu, S.; Takata, F.; Machida, T.; Bölükbaşi Hatip, F.F.; Hatip-Al-Khatib, I.; Yamauchi, A.; Kataoka, Y. TNF- $\alpha$ -

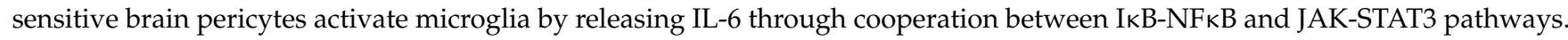
Brain Res. 2018, 1692, 34-44. [CrossRef] [PubMed]

14. Armulik, A.; Genové, G.; Mäe, M.; Nisancioglu, M.H.; Wallgard, E.; Niaudet, C.; He, L.; Norlin, J.; Lindblom, P.; Strittmatter, K.; et al. Pericytes regulate the blood-brain barrier. Nature 2010, 468, 557-561. [CrossRef] [PubMed]

15. Armulik, A.; Genové, G.; Betsholtz, C. Pericytes: Developmental, physiological, and pathological perspectives, problems, and promises. Dev. Cell 2011, 21, 193-215. [CrossRef] [PubMed]

16. Sweeney, M.D.; Zhao, Z.; Montagne, A.; Nelson, A.R.; Zlokovic, B.V. Blood-Brain Barrier: From Physiology to Disease and Back. Physiol. Rev. 2019, 99, 21-78. [CrossRef]

17. Winkler, E.A.; Bell, R.D.; Zlokovic, B.V. Central nervous system pericytes in health and disease. Nat. Neurosci. 2011, 14, 1398-1405. [CrossRef]

18. Stark, K.; Eckart, A.; Haidari, S.; Tirniceriu, A.; Lorenz, M.; von Brühl, M.L.; Gärtner, F.; Khandoga, A.G.; Legate, K.R.; Pless, R.; et al. Capillary and arteriolar pericytes attract innate leukocytes exiting through venules and 'instruct' them with pattern-recognition and motility programs. Nat. Immunol. 2013, 14, 41-51. [CrossRef]

19. Xu, D.; Robinson, A.P.; Ishii, T.; Duncan, D.S.; Alden, T.D.; Goings, G.E.; Ifergan, I.; Podojil, J.R.; Penaloza-MacMaster, P.; Kearney, J.A.; et al. Peripherally derived $\mathrm{T}$ regulatory and gammadelta $\mathrm{T}$ cells have opposing roles in the pathogenesis of intractable pediatric epilepsy. J. Exp. Med. 2018, 215, 1169-1186. [CrossRef] [PubMed]

20. Yamanaka, G.; Morichi, S.; Takamatsu, T.; Watanabe, Y.; Suzuki, S.; Ishida, Y.; Oana, S.; Yamazaki, T.; Takata, F.; Kawashima, H. Links between Immune Cells from the Periphery and the Brain in the Pathogenesis of Epilepsy: A Narrative Review. Int. J. Mol. Sci. 2021, 22, 4395. [CrossRef]

21. Fernández-Klett, F.; Potas, J.R.; Hilpert, D.; Blazej, K.; Radke, J.; Huck, J.; Engel, O.; Stenzel, W.; Genové, G.; Priller, J. Early loss of pericytes and perivascular stromal cell-induced scar formation after stroke. J. Cereb. Blood Flow Metab. 2013, 33, 428-439. [CrossRef]

22. Göritz, C.; Dias, D.O.; Tomilin, N.; Barbacid, M.; Shupliakov, O.; Frisén, J. A pericyte origin of spinal cord scar tissue. Science 2011, 333, 238-242. [CrossRef]

23. Reeves, C.; Pradim-Jardim, A.; Sisodiya, S.M.; Thom, M.; Liu, J.Y.W. Spatiotemporal dynamics of PDGFR $\beta$ expression in pericytes and glial scar formation in penetrating brain injuries in adults. Neuropathol. Appl. Neurobiol. 2019, 45, 609-627. [CrossRef]

24. Rivera, F.J.; Hinrichsen, B.; Silva, M.E. Pericytes in Multiple Sclerosis. Adv. Exp. Med. Biol. 2019, 1147, 167-187. [CrossRef] [PubMed]

25. Garbelli, R.; de Bock, F.; Medici, V.; Rousset, M.C.; Villani, F.; Boussadia, B.; Arango-Lievano, M.; Jeanneteau, F.; Daneman, R.; Bartolomei, F.; et al. PDGFR $\beta(+)$ cells in human and experimental neuro-vascular dysplasia and seizures. Neuroscience 2015, 306, 18-27. [CrossRef]

26. Jansson, D.; Scotter, E.L.; Rustenhoven, J.; Coppieters, N.; Smyth, L.C.; Oldfield, R.L.; Bergin, P.S.; Mee, E.W.; Graham, E.S.; Faull, R.L.; et al. Interferon- $\gamma$ blocks signalling through PDGFR $\beta$ in human brain pericytes. J. Neuroinflamm. 2016, 13, 249. [CrossRef] [PubMed] 
27. Rustenhoven, J.; Aalderink, M.; Scotter, E.L.; Oldfield, R.L.; Bergin, P.S.; Mee, E.W.; Graham, E.S.; Faull, R.L.; Curtis, M.A.; Park, T.I.; et al. TGF-beta1 regulates human brain pericyte inflammatory processes involved in neurovasculature function. $J$. Neuroinflamm. 2016, 13, 37. [CrossRef]

28. Arango-Lievano, M.; Boussadia, B.; De Terdonck, L.D.T.; Gault, C.; Fontanaud, P.; Lafont, C.; Mollard, P.; Marchi, N.; Jeanneteau, F. Topographic Reorganization of Cerebrovascular Mural Cells under Seizure Conditions. Cell Rep. 2018, 23, 1045-1059. [CrossRef]

29. Klement, W.; Garbelli, R.; Zub, E.; Rossini, L.; Tassi, L.; Girard, B.; Blaquiere, M.; Bertaso, F.; Perroy, J.; de Bock, F.; et al. Seizure progression and inflammatory mediators promote pericytosis and pericyte-microglia clustering at the cerebrovasculature. Neurobiol. Dis. 2018, 113, 70-81. [CrossRef]

30. Klement, W.; Blaquiere, M.; Zub, E.; deBock, F.; Boux, F.; Barbier, E.; Audinat, E.; Lerner-Natoli, M.; Marchi, N. A pericyte-glia scarring develops at the leaky capillaries in the hippocampus during seizure activity. Epilepsia 2019, 60, 1399-1411. [CrossRef] [PubMed]

31. Prager, O.; Kamintsky, L.; Hasam-Henderson, L.A.; Schoknecht, K.; Wuntke, V.; Papageorgiou, I.; Swolinsky, J.; Muoio, V.; Bar-Klein, G.; Vazana, U.; et al. Seizure-induced microvascular injury is associated with impaired neurovascular coupling and blood-brain barrier dysfunction. Epilepsia 2019, 60, 322-336. [CrossRef] [PubMed]

32. Sakai, K.; Takata, F.; Yamanaka, G.; Yasunaga, M.; Hashiguchi, K.; Tominaga, K.; Itoh, K.; Kataoka, Y.; Yamauchi, A.; Dohgu, S. Reactive pericytes in early phase are involved in glial activation and late-onset hypersusceptibility to pilocarpine-induced seizures in traumatic brain injury model mice. J. Pharmacol. Sci. 2021, 145, 155-165. [CrossRef]

33. Sweeney, M.D.; Ayyadurai, S.; Zlokovic, B.V. Pericytes of the neurovascular unit: Key functions and signaling pathways. Nat. Neurosci. 2016, 19, 771-783. [CrossRef]

34. Cheng, J.; Korte, N.; Nortley, R.; Sethi, H.; Tang, Y.; Attwell, D. Targeting pericytes for therapeutic approaches to neurological disorders. Acta Neuropathol. 2018, 136, 507-523. [CrossRef]

35. Rouget, C. Note sur le developpement de la tunique contractile des vaisseaux. C. R. L'académie Sci. 1874, 59, 559-562.

36. Zimmermann, K.W. Der feinere bau der blutcapillares. Z. Anat. Entwicklungsgesch. 1923, 68, 3-109. [CrossRef]

37. Ando, K.; Fukuhara, S.; Izumi, N.; Nakajima, H.; Fukui, H.; Kelsh, R.N.; Mochizuki, N. Clarification of mural cell coverage of vascular endothelial cells by live imaging of zebrafish. Development 2016, 143, 1328-1339. [CrossRef] [PubMed]

38. Winkler, E.A.; Bell, R.D.; Zlokovic, B.V. Pericyte-specific expression of PDGF beta receptor in mouse models with normal and deficient PDGF beta receptor signaling. Mol. Neurodegener. 2010, 5, 32. [CrossRef] [PubMed]

39. Thomsen, M.S.; Routhe, L.J.; Moos, T. The vascular basement membrane in the healthy and pathological brain. J. Cereb. Blood Flow Metab. 2017, 37, 3300-3317. [CrossRef] [PubMed]

40. Hellström, M.; Kalén, M.; Lindahl, P.; Abramsson, A.; Betsholtz, C. Role of PDGF-B and PDGFR-beta in recruitment of vascular smooth muscle cells and pericytes during embryonic blood vessel formation in the mouse. Development 1999, 126, $3047-3055$. [CrossRef]

41. Lindahl, P.; Johansson, B.R.; Levéen, P.; Betsholtz, C. Pericyte loss and microaneurysm formation in PDGF-B-deficient mice. Science 1997, 277, 242-245. [CrossRef]

42. Nikolakopoulou, A.M.; Montagne, A.; Kisler, K.; Dai, Z.; Wang, Y.; Huuskonen, M.T.; Sagare, A.P.; Lazic, D.; Sweeney, M.D.; Kong, P.; et al. Pericyte loss leads to circulatory failure and pleiotrophin depletion causing neuron loss. Nat. Neurosci. 2019, 22, 1089-1098. [CrossRef]

43. Bhattacharya, A.; Kaushik, D.K.; Lozinski, B.M.; Yong, V.W. Beyond barrier functions: Roles of pericytes in homeostasis and regulation of neuroinflammation. J. Neurosci. Res. 2020, 98, 2390-2405. [CrossRef]

44. Vanlandewijck, M.; He, L.; Mäe, M.A.; Andrae, J.; Ando, K.; Del Gaudio, F.; Nahar, K.; Lebouvier, T.; Laviña, B.; Gouveia, L.; et al. A molecular atlas of cell types and zonation in the brain vasculature. Nature 2018, 554, 475-480. [CrossRef]

45. Attwell, D.; Mishra, A.; Hall, C.N.; O’Farrell, F.M.; Dalkara, T. What is a pericyte? J. Cereb. Blood Flow Metab. 2016, 36, 451-455. [CrossRef] [PubMed]

46. Marques, S.; van Bruggen, D.; Vanichkina, D.P.; Floriddia, E.M.; Munguba, H.; Väremo, L.; Giacomello, S.; Falcão, A.M.; Meijer, M.; Björklund, Å.K.; et al. Transcriptional Convergence of Oligodendrocyte Lineage Progenitors during Development. Dev. Cell 2018, 46, 504-517.e7. [CrossRef]

47. Bondjers, C.; He, L.; Takemoto, M.; Norlin, J.; Asker, N.; Hellström, M.; Lindahl, P.; Betsholtz, C. Microarray analysis of blood microvessels from PDGF-B and PDGF-Rbeta mutant mice identifies novel markers for brain pericytes. FASEB J. 2006, 20, 1703-1705. [CrossRef]

48. Iacobaeus, E.; Sugars, R.V.; Törnqvist Andrén, A.; Alm, J.J.; Qian, H.; Frantzen, J.; Newcombe, J.; Alkass, K.; Druid, H.; Bottai, M.; et al. Dynamic Changes in Brain Mesenchymal Perivascular Cells Associate with Multiple Sclerosis Disease Duration, Active Inflammation, and Demyelination. Stem. Cells Transl. Med. 2017, 6, 1840-1851. [CrossRef] [PubMed]

49. Zeisel, A.; Hochgerner, H.; Lönnerberg, P.; Johnsson, A.; Memic, F.; van der Zwan, J.; Häring, M.; Braun, E.; Borm, L.E.; La Manno, G.; et al. Molecular Architecture of the Mouse Nervous System. Cell 2018, 174, 999-1014.e22. [CrossRef]

50. Damisah, E.C.; Hill, R.A.; Tong, L.; Murray, K.N.; Grutzendler, J. A fluoro-Nissl dye identifies pericytes as distinct vascular mural cells during in vivo brain imaging. Nat. Neurosci. 2017, 20, 1023-1032. [CrossRef] [PubMed]

51. Sweeney, M.D.; Sagare, A.P.; Zlokovic, B.V. Blood-brain barrier breakdown in Alzheimer disease and other neurodegenerative disorders. Nat. Rev. Neurol. 2018, 14, 133-150. [CrossRef] 
52. Navarro, R.; Compte, M.; Álvarez-Vallina, L.; Sanz, L. Immune Regulation by Pericytes: Modulating Innate and Adaptive Immunity. Front. Immunol. 2016, 7, 480. [CrossRef]

53. Nehmé, A.; Edelman, J. Dexamethasone inhibits high glucose-, TNF-alpha-, and IL-1beta-induced secretion of inflammatory and angiogenic mediators from retinal microvascular pericytes. Investig. Ophthalmol. Vis. Sci. 2008, 49, 2030-2038. [CrossRef]

54. Fabene, P.F.; Bramanti, P.; Constantin, G. The emerging role for chemokines in epilepsy. J. Neuroimmunol. 2010, $224,22-27$. [CrossRef] [PubMed]

55. Vezzani, A.; Aronica, E.; Mazarati, A.; Pittman, Q.J. Epilepsy and brain inflammation. Exp. Neurol. 2013, 244, 11-21. [CrossRef] [PubMed]

56. Glass, C.K.; Saijo, K.; Winner, B.; Marchetto, M.C.; Gage, F.H. Mechanisms underlying inflammation in neurodegeneration. Cell 2010, 140, 918-934. [CrossRef] [PubMed]

57. Kim, J.Y.; Kim, N.; Yenari, M.A. Mechanisms and potential therapeutic applications of microglial activation after brain injury. CNS Neurosci. Ther. 2015, 21, 309-319. [CrossRef]

58. Gutierrez, H.; Hale, V.A.; Dolcet, X.; Davies, A. NF-kappaB signalling regulates the growth of neural processes in the developing PNS and CNS. Development 2005, 132, 1713-1726. [CrossRef] [PubMed]

59. Bodnar, R.J.; Yang, T.; Rigatti, L.H.; Liu, F.; Evdokiou, A.; Kathju, S.; Satish, L. Pericytes reduce inflammation and collagen deposition in acute wounds. Cytotherapy 2018, 20, 1046-1060. [CrossRef]

60. Minutti, C.M.; Modak, R.V.; Macdonald, F.; Li, F.; Smyth, D.J.; Dorward, D.A.; Blair, N.; Husovsky, C.; Muir, A.; Giampazolias, E.; et al. A Macrophage-Pericyte Axis Directs Tissue Restoration via Amphiregulin-Induced Transforming Growth Factor Beta Activation. Immunity 2019, 50, 645-654.e6. [CrossRef]

61. Gaceb, A.; Özen, I.; Padel, T.; Barbariga, M.; Paul, G. Pericytes secrete pro-regenerative molecules in response to platelet-derived growth factor-BB. J. Cereb. Blood Flow Metab. 2018, 38, 45-57. [CrossRef]

62. Ishitsuka, K.; Ago, T.; Arimura, K.; Nakamura, K.; Tokami, H.; Makihara, N.; Kuroda, J.; Kamouchi, M.; Kitazono, T. Neurotrophin production in brain pericytes during hypoxia: A role of pericytes for neuroprotection. Microvasc. Res. 2012, 83, 352-359. [CrossRef] [PubMed]

63. Liwnicz, B.H.; Leach, J.L.; Yeh, H.S.; Privitera, M. Pericyte degeneration and thickening of basement membranes of cerebral microvessels in complex partial seizures: Electron microscopic study of surgically removed tissue. Neurosurgery 1990, 26, 409-420. [CrossRef]

64. Van Vliet, E.A.; da Costa Araújo, S.; Redeker, S.; van Schaik, R.; Aronica, E.; Gorter, J.A. Blood-brain barrier leakage may lead to progression of temporal lobe epilepsy. Brain 2007, 130, 521-534. [CrossRef]

65. Marchi, N.; Angelov, L.; Masaryk, T.; Fazio, V.; Granata, T.; Hernandez, N.; Hallene, K.; Diglaw, T.; Franic, L.; Najm, I.; et al. Seizure-promoting effect of blood-brain barrier disruption. Epilepsia 2007, 48, 732-742. [CrossRef]

66. Marchi, N.; Granata, T.; Ghosh, C.; Janigro, D. Blood-brain barrier dysfunction and epilepsy: Pathophysiologic role and therapeutic approaches. Epilepsia 2012, 53, 1877-1886. [CrossRef]

67. Uprety, A.; Kang, Y.; Kim, S.Y. Blood-brain barrier dysfunction as a potential therapeutic target for neurodegenerative disorders. Arch. Pharm. Res. 2021, 44, 487-498. [CrossRef] [PubMed]

68. Ivens, S.; Kaufer, D.; Flores, L.P.; Bechmann, I.; Zumsteg, D.; Tomkins, O.; Seiffert, E.; Heinemann, U.; Friedman, A. TGF-beta receptor-mediated albumin uptake into astrocytes is involved in neocortical epileptogenesis. Brain 2007, 130, 535-547. [CrossRef]

69. Weissberg, I.; Wood, L.; Kamintsky, L.; Vazquez, O.; Milikovsky, D.Z.; Alexander, A.; Oppenheim, H.; Ardizzone, C.; Becker, A.; Frigerio, F; et al. Albumin induces excitatory synaptogenesis through astrocytic TGF- $\beta$ /ALK5 signaling in a model of acquired epilepsy following blood-brain barrier dysfunction. Neurobiol. Dis. 2015, 78, 115-125. [CrossRef]

70. Pieper, C.; Marek, J.J.; Unterberg, M.; Schwerdtle, T.; Galla, H.J. Brain capillary pericytes contribute to the immune defense in response to cytokines or LPS in vitro. Brain Res. 2014, 1550, 1-8. [CrossRef] [PubMed]

71. Galea, I.; Bernardes-Silva, M.; Forse, P.A.; van Rooijen, N.; Liblau, R.S.; Perry, V.H. An antigen-specific pathway for CD8 T cells across the blood-brain barrier. J. Exp. Med. 2007, 204, 2023-2030. [CrossRef]

72. Fabene, P.F.; Mora, G.N.; Martinello, M.; Rossi, B.; Merigo, F.; Ottoboni, L.; Bach, S.; Angiari, S.; Benati, D.; Chakir, A.; et al. A role for leukocyte-endothelial adhesion mechanisms in epilepsy. Nat. Med. 2008, 14, 1377-1383. [CrossRef] [PubMed]

73. Ravizza, T.; Gagliardi, B.; Noe, F.; Boer, K.; Aronica, E.; Vezzani, A. Innate and adaptive immunity during epileptogenesis and spontaneous seizures: Evidence from experimental models and human temporal lobe epilepsy. Neurobiol. Dis. 2008, $29,142-160$. [CrossRef] [PubMed]

74. Marchi, N.; Teng, Q.; Ghosh, C.; Fan, Q.; Nguyen, M.T.; Desai, N.K.; Bawa, H.; Rasmussen, P.; Masaryk, T.K.; Janigro, D. Blood-brain barrier damage, but not parenchymal white blood cells, is a hallmark of seizure activity. Brain Res. 2010, 1353, 176-186. [CrossRef]

75. Varvel, N.H.; Neher, J.J.; Bosch, A.; Wang, W.; Ransohoff, R.M.; Miller, R.J.; Dingledine, R. Infiltrating monocytes promote brain inflammation and exacerbate neuronal damage after status epilepticus. Proc. Natl. Acad. Sci. USA 2016, 113, E5665-E5674. [CrossRef]

76. Broekaart, D.W.M.; Anink, J.J.; Baayen, J.C.; Idema, S.; de Vries, H.E.; Aronica, E.; Gorter, J.A.; van Vliet, E.A. Activation of the innate immune system is evident throughout epileptogenesis and is associated with blood-brain barrier dysfunction and seizure progression. Epilepsia 2018, 59, 1931-1944. [CrossRef] [PubMed] 
77. Aronica, E.; Bauer, S.; Bozzi, Y.; Caleo, M.; Dingledine, R.; Gorter, J.A.; Henshall, D.C.; Kaufer, D.; Koh, S.; Loscher, W.; et al. Neuroinflammatory targets and treatments for epilepsy validated in experimental models. Epilepsia 2017, 58 (Suppl. S3), 27-38. [CrossRef]

78. Feng, L.; Murugan, M.; Bosco, D.B.; Liu, Y.; Peng, J.; Worrell, G.A.; Wang, H.L.; Ta, L.E.; Richardson, J.R.; Shen, Y.; et al. Microglial proliferation and monocyte infiltration contribute to microgliosis following status epilepticus. Glia 2019, 67, 1434-1448. [CrossRef]

79. Yamanaka, G.; Takamatsu, T.; Morichi, S.; Yamazaki, T.; Mizoguchi, I.; Ohno, K.; Watanabe, Y.; Ishida, Y.; Oana, S.; Suzuki, S.; et al. Interleukin-1 $\beta$ in peripheral monocytes is associated with seizure frequency in pediatric drug-resistant epilepsy. J. Neuroimmunol. 2021, 352, 577475. [CrossRef] [PubMed]

80. Boer, K.; Spliet, W.G.; van Rijen, P.C.; Redeker, S.; Troost, D.; Aronica, E. Evidence of activated microglia in focal cortical dysplasia. J. Neuroimmunol. 2006, 173, 188-195. [CrossRef]

81. Swissa, E.; Serlin, Y.; Vazana, U.; Prager, O.; Friedman, A. Blood-brain barrier dysfunction in status epileptics: Mechanisms and role in epileptogenesis. Epilepsy Behav. 2019, 101, 106285. [CrossRef]

82. Logan, A.; Berry, M.; Gonzalez, A.M.; Frautschy, S.A.; Sporn, M.B.; Baird, A. Effects of transforming growth factor beta 1 on scar production in the injured central nervous system of the rat. Eur. J. Neurosci. 1994, 6, 355-363. [CrossRef] [PubMed]

83. Lindholm, D.; Castrén, E.; Kiefer, R.; Zafra, F.; Thoenen, H. Transforming growth factor-beta 1 in the rat brain: Increase after injury and inhibition of astrocyte proliferation. J. Cell Biol. 1992, 117, 395-400. [CrossRef] [PubMed]

84. Pierce, G.F.; Mustoe, T.A.; Lingelbach, J.; Masakowski, V.R.; Griffin, G.L.; Senior, R.M.; Deuel, T.F. Platelet-derived growth factor and transforming growth factor-beta enhance tissue repair activities by unique mechanisms. J. Cell Biol. 1989, 109, 429-440. [CrossRef]

85. Aronica, E.; van Vliet, E.A.; Mayboroda, O.A.; Troost, D.; da Silva, F.H.; Gorter, J.A. Upregulation of metabotropic glutamate receptor subtype mGluR3 and mGluR5 in reactive astrocytes in a rat model of mesial temporal lobe epilepsy. Eur. J. Neurosci. 2000, 12, 2333-2344. [CrossRef]

86. Dohgu, S.; Takata, F.; Yamauchi, A.; Nakagawa, S.; Egawa, T.; Naito, M.; Tsuruo, T.; Sawada, Y.; Niwa, M.; Kataoka, Y. Brain pericytes contribute to the induction and up-regulation of blood-brain barrier functions through transforming growth factor-beta production. Brain Res. 2005, 1038, 208-215. [CrossRef] [PubMed]

87. Bar-Klein, G.; Cacheaux, L.P.; Kamintsky, L.; Prager, O.; Weissberg, I.; Schoknecht, K.; Cheng, P.; Kim, S.Y.; Wood, L.; Heinemann, U.; et al. Losartan prevents acquired epilepsy via TGF- $\beta$ signaling suppression. Ann. Neurol. 2014, 75, 864-875. [CrossRef] [PubMed]

88. Lim, D.S.; Lutucuta, S.; Bachireddy, P.; Youker, K.; Evans, A.; Entman, M.; Roberts, R.; Marian, A.J. Angiotensin II blockade reverses myocardial fibrosis in a transgenic mouse model of human hypertrophic cardiomyopathy. Circulation 2001, 103, 789-791. [CrossRef] [PubMed]

89. Lavoie, P.; Robitaille, G.; Agharazii, M.; Ledbetter, S.; Lebel, M.; Larivière, R. Neutralization of transforming growth factor-beta attenuates hypertension and prevents renal injury in uremic rats. J. Hypertens. 2005, 23, 1895-1903. [CrossRef]

90. Nadal, J.A.; Scicli, G.M.; Carbini, L.A.; Nussbaum, J.J.; Scicli, A.G. Angiotensin II and retinal pericytes migration. Biochem. Biophys. Res. Commun. 1999, 266, 382-385. [CrossRef] [PubMed]

91. Benicky, J.; Sánchez-Lemus, E.; Honda, M.; Pang, T.; Orecna, M.; Wang, J.; Leng, Y.; Chuang, D.M.; Saavedra, J.M. Angiotensin II AT1 receptor blockade ameliorates brain inflammation. Neuropsychopharmacology 2011, 36, 857-870. [CrossRef]

92. Bull, N.D.; Johnson, T.V.; Welsapar, G.; DeKorver, N.W.; Tomarev, S.I.; Martin, K.R. Use of an adult rat retinal explant model for screening of potential retinal ganglion cell neuroprotective therapies. Investig. Ophthalmol. Vis. Sci. 2011, 52, 3309-3320. [CrossRef]

93. Xiao, B.G.; Link, H. IFN-gamma production of adult rat astrocytes triggered by TNF-alpha. Neuroreport 1998, 9, 1487-1490. [CrossRef]

94. Wei, Y.P.; Kita, M.; Shinmura, K.; Yan, X.Q.; Fukuyama, R.; Fushiki, S.; Imanishi, J. Expression of IFN-gamma in cerebrovascular endothelial cells from aged mice. J. Interferon Cytokine Res. 2000, 20, 403-409. [CrossRef]

95. Lau, L.T.; Yu, A.C. Astrocytes produce and release interleukin-1, interleukin-6, tumor necrosis factor alpha and interferon-gamma following traumatic and metabolic injury. J. Neurotrauma 2001, 18, 351-359. [CrossRef]

96. Mount, M.P.; Lira, A.; Grimes, D.; Smith, P.D.; Faucher, S.; Slack, R.; Anisman, H.; Hayley, S.; Park, D.S. Involvement of interferon-gamma in microglial-mediated loss of dopaminergic neurons. J. Neurosci. 2007, 27, 3328-3337. [CrossRef] [PubMed]

97. Kreutzfeldt, M.; Bergthaler, A.; Fernandez, M.; Brück, W.; Steinbach, K.; Vorm, M.; Coras, R.; Blümcke, I.; Bonilla, W.V.; Fleige, A.; et al. Neuroprotective intervention by interferon- $\gamma$ blockade prevents CD8+ T cell-mediated dendrite and synapse loss. J. Exp. Med. 2013, 210, 2087-2103. [CrossRef]

98. Li, T.; Zhai, X.; Jiang, J.; Song, X.; Han, W.; Ma, J.; Xie, L.; Cheng, L.; Chen, H.; Jiang, L. Intraperitoneal injection of IL-4/IFN- $\gamma$ modulates the proportions of microglial phenotypes and improves epilepsy outcomes in a pilocarpine model of acquired epilepsy. Brain Res. 2017, 1657, 120-129. [CrossRef]

99. Vezzani, A.; French, J.; Bartfai, T.; Baram, T.Z. The role of inflammation in epilepsy. Nat. Rev. Neurol. 2011, 7, 31-40. [CrossRef] [PubMed]

100. Jyonouchi, H.; Geng, L. Intractable Epilepsy (IE) and Responses to Anakinra, a Human Recombinant IL-1 Receptor Agonist (IL-1ra): Case Reports. J. Clin. Cell. Immunol. 2016, 7. [CrossRef] 
101. Kenney-Jung, D.L.; Vezzani, A.; Kahoud, R.J.; LaFrance-Corey, R.G.; Ho, M.L.; Muskardin, T.W.; Wirrell, E.C.; Howe, C.L.; Payne, E.T. Febrile infection-related epilepsy syndrome treated with anakinra. Ann. Neurol. 2016, 80, 939-945. [CrossRef]

102. Dilena, R.; Mauri, E.; Aronica, E.; Bernasconi, P.; Bana, C.; Cappelletti, C.; Carrabba, G.; Ferrero, S.; Giorda, R.; Guez, S.; et al. Therapeutic effect of Anakinra in the relapsing chronic phase of febrile infection-related epilepsy syndrome. Epilepsia Open 2019, 4, 344-350. [CrossRef] [PubMed]

103. Clarkson, B.D.S.; LaFrance-Corey, R.G.; Kahoud, R.J.; Farias-Moeller, R.; Payne, E.T.; Howe, C.L. Functional deficiency in endogenous interleukin-1 receptor antagonist in patients with febrile infection-related epilepsy syndrome. Ann. Neurol. 2019, 85, 526-537. [CrossRef]

104. Paglinawan, R.; Malipiero, U.; Schlapbach, R.; Frei, K.; Reith, W.; Fontana, A. TGFbeta directs gene expression of activated microglia to an anti-inflammatory phenotype strongly focusing on chemokine genes and cell migratory genes. Glia 2003, 44 , 219-231. [CrossRef]

105. Lodge, P.A.; Sriram, S. Regulation of microglial activation by TGF-beta, IL-10, and CSF-1. J. Leukoc. Biol. 1996, 60, 502-508. [CrossRef]

106. Smith, A.M.; Graham, E.S.; Feng, S.X.; Oldfield, R.L.; Bergin, P.M.; Mee, E.W.; Faull, R.L.; Curtis, M.A.; Dragunow, M. Adult human glia, pericytes and meningeal fibroblasts respond similarly to IFNy but not to TGF $\beta 1$ or M-CSF. PLoS ONE 2013, 8, e80463. [CrossRef]

107. Brionne, T.C.; Tesseur, I.; Masliah, E.; Wyss-Coray, T. Loss of TGF-beta 1 leads to increased neuronal cell death and microgliosis in mouse brain. Neuron 2003, 40, 1133-1145. [CrossRef]

108. Klein, P.; Friedman, A.; Hameed, M.Q.; Kaminski, R.M.; Bar-Klein, G.; Klitgaard, H.; Koepp, M.; Jozwiak, S.; Prince, D.A.; Rotenberg, A.; et al. Repurposed molecules for antiepileptogenesis: Missing an opportunity to prevent epilepsy? Epilepsia 2020, 61, 359-386. [CrossRef]

109. Stebbins, M.J.; Gastfriend, B.D.; Canfield, S.G.; Lee, M.S.; Richards, D.; Faubion, M.G.; Li, W.J.; Daneman, R.; Palecek, S.P.; Shusta, E.V. Human pluripotent stem cell-derived brain pericyte-like cells induce blood-brain barrier properties. Sci. Adv. 2019, 5, eaau7375. [CrossRef] [PubMed] 